\title{
THINKING TOGETHER
}

LECTURING, LEARNING, AND DIFFERENCE

IN THE LONG NINETEENTH CENTURY

EDITED BY ANGELA G. RAY AND PAUL STOB

The Pennsylvania State University Press University Park, Pennsylvania 


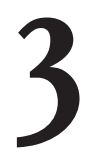

MOBILIZING IRISH AMERICA

IN THE ANTEBELLUM LECTURE HALL

Tom F. Wright

The American speaking circuit occupies an indelible place in the history of what James Joyce called "our greater Ireland beyond the sea." ${ }^{1}$ Given the presence of a large diaspora, a receptive political culture, and the prospect of support both moral and material, public appearances on the platforms of the United States have been a key arena of action for those seeking to shape visions of Ireland's future. The mid-nineteenth century represents an important chapter in this story. In the wake of the mass emigration of the famine period and the failed I848 Young Ireland uprising against British rule, a great deal of cultural, political, and intellectual energy shifted west across the Atlantic, where the newly consolidated phenomenon of the American popular lecture system became a means by which the challenges and opportunities of global Irish identity could be articulated and reimagined. This chapter explores two distinct ways this was attempted during the antebellum period: through spectacles of Irish nationalism and through the words of orators eager to challenge dominant ideas about "Celtic" and "Anglo-Saxon" racial theory.

The list of nationalists who have made their case at American lecterns is a roll call of modern Irish political history: from Charles Parnell and John Redmond in the I88os through Countess Constance Markievicz and Hanna Sheehy-Skeffington in the years surrounding the I9I6 Easter Rising to Sinn Féin's Gerry Adams in the I990s. ${ }^{2}$ All have demonstrated a keenly instrumental understanding of what the lecture hall could mean in practical terms and what it could stand for as a symbol. In this chapter, I make the case that this political tradition effectively begins with the spectacular appearances of escaped fugitive nationalists Thomas Francis Meagher and John Mitchel in 
the early I850s. Both used oratory as part of an array of flamboyant forms of publicity, with the aim of simultaneously mobilizing a radical diaspora and a counterpublic of Americans sympathetic to republican political ideals and reimagining the public lecture as political theater. However, as I show, during the same years the American platform also played host to other, more rarefied intellectual discussions of Irish and "Celtic" identity. Inspired by strands of popular polygenist racial theory, Irish lecturers such as John McElheran used pseudoscientific ethnology to push against the prevailing discourse of Anglo-Saxon superiority and to argue for the innate democratic potential of the Celt. In these ways, by thinking together in the lecture hall about the realities and illusions of apparent differences, and about the types of togetherness involved in political commitments, one of the most important generations of thinkers and agitators in Irish American history mounted a powerful challenge to an overarching "Anglo-American commons."

This last phrase is one that I use in my book Lecturing the Atlantic, where I argue that the lecture platform of the period was strongly patterned by its engagement with a quite different form of diasporic identity: that of an elaborate fascination with England and the Anglo-American connection. ${ }^{3}$ Lectures about Oliver Cromwell or Shakespeare, lectures about travel in England and the "Anglo-Saxon race," or appearances by British writers such as William Makepeace Thackeray were among the most reliable crowd-pullers on any lecture program. The Anglo-obsession of lecture culture reached its apogee during the social turmoil of the I840s, when it can be read as an assertive response to the pace of demographic change, especially in urban centers such as New York, where by the mid-1850s almost one-third of residents were Irish-born. Although the early lyceum promoter Josiah Holbrook had intended a diverse audience, the reality rarely lived up to this ideal. Thomas Wentworth Higginson observed of the period in I868, "Foreign immigrants are apt to avoid [the lecture hall] or to taste of it, as they do of any other national dish, with courtesy, but not with relish." ${ }^{4}$ As Andrew Chamberlin Rieser has noted, "The rise of nativism after the lyceum vogue is not entirely coincidental." ${ }^{5}$ The ubiquity of lectures on British themes was one way the mainstream platform helped to enforce a normative ethnic identity.

My book argues that the lecture hall provided a galvanizing space where an "Anglo-American commons" might find its expression. I employ the term commons in two related senses. First, it refers to the sense of a shared ethnic lineage; second, and in a more abstract sense, it denotes the shared symbolic resources of culture, language, and history that were seen to unite Great Britain and the United States. ${ }^{6}$ As I show, the American lecture hall was 


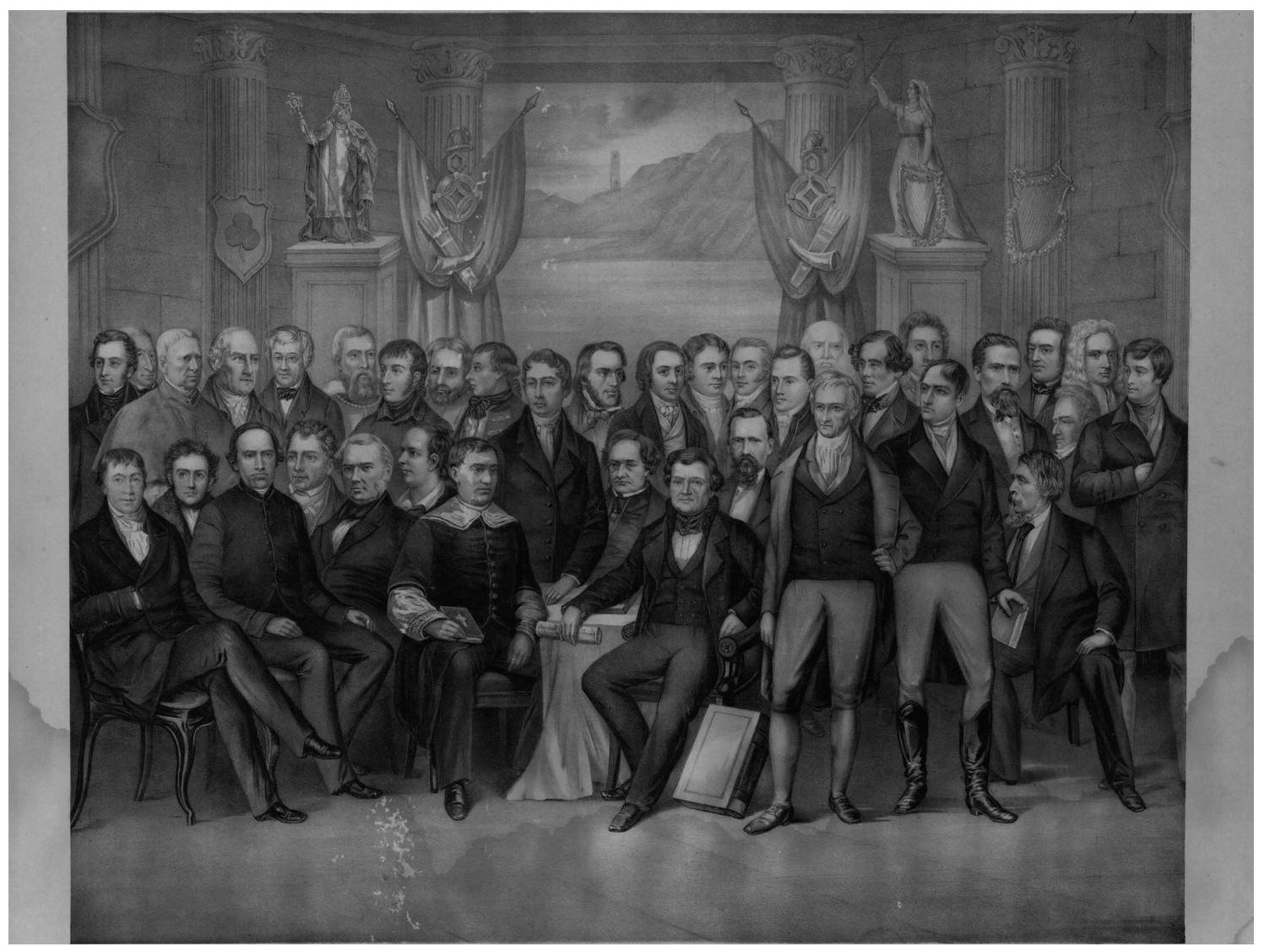

Figure 3.1 Erin go bragh, circa I879-85. This imaginary group portrait of patriotic Irishmen throughout history was published by New York's Fishel, Adler and Company. Its depictions include four Irish emigrants to the United States: Colonel Patrick Kelly, Thomas Meagher, John Mitchel, and Jeremiah O’Donovan Rossa. Courtesy of the American Antiquarian Society.

an arena in which ideas about an Anglo-American commons found some of their most prominent articulations. Yet as this chapter explores, it was also a space in which these ideas were challenged in powerful ways. In antebellum America, a range of performers questioned the relevance or importance of British inheritance, overturned historical myths, and revealed the material limits of a notionally shared culture. Native American lecturers, African American literary societies, and German-language lyceums, among others, all existed at the edge of this normative center, and as the present volume confirms, recent scholarship is continuing to uncover fascinating new evidence of the importance and scope of such groups. What follows is an attempt to begin something similar for the Irish American presence on the antebellum platform, an involvement that remains unexplored to date in most narratives of lecture culture, although historians of Irish nationalism 
and of Victorian scientific culture have touched on the experiences of some of the figures I discuss. ${ }^{7}$ By drawing these contexts together, my aim is to offer a series of fresh, suggestive juxtapositions amid the tangled history of the Green Atlantic and to contribute to an understanding of lecturing as a rich and still overlooked element of a North Atlantic performance continuum that unites the worlds of theater, science, and political agitation. ${ }^{8}$

Meagher, Mitchel, and the Theater of Republicanism

Perhaps the most visible Irishman on the antebellum American platform was Meagher, the first of the leaders of the I 848 uprising to translate his experience for lecture hall audiences. Having dramatically escaped imprisonment in Van Diemen's Land (later Tasmania), he sought passage to New York by way of Brazil in mid-I852. In the words of Henry Ward Beecher, "When it was announced that Meagher had escaped from the convict-isle, the continent rang with congratulation." The flamboyant, handsome Meagher was welcomed to North America as a global statesman, already famous for his oratory thanks to his widely reprinted I 846 "sword speech," in which he had memorably praised the "redeeming magic" of the American Revolution. ${ }^{10}$ He soon bowed to the many invitations to speak on the public lecture circuit about his experiences, and his earliest U.S. appearances caused a sensation. The first engagement, at Manhattan's Metropolitan Hall, drew what one reporter thought "the largest audience ever assembled in this city to hear one man speak, where a charge was made for admission"; the event garnered "a larger sum than was ever produced by a lecture at New York."11 Initially, Meagher spoke mainly about his prison experiences in the Australian penal colony, using such reflections to campaign for the "progress of republicanism in England and throughout the English colonies." 12 Soon he developed a wider repertoire, speaking to audiences across the country about "Great Irish Orators." ${ }^{13}$ Having taken his reflections throughout New England, Ohio, Michigan, and Missouri, he also toured the South, and in I853 he spoke before President-elect Franklin Pierce in Washington. He soon established himself as editor of the Irish News in New York, before finding lasting fame in his adopted country as a heroic Union general during the Civil War.

His fellow nationalist leader John Mitchel had read accounts of Meagher's exploits and transcripts of his lectures from his own imprisonment in Bermuda, where he was busy composing the Jail Journal (1854), which was to become a canonical text of Irish nationalism. Having resolved to follow 
Meagher to the United States, Mitchel, too, secured escape, and he arrived in New York by way of California in November I853. He was feted in much the same manner as Meagher and soon turned to the lecture platform himself, offering lectures that were even more militant and polemical than those of his compatriot. During I854-55 he toured the Eastern seaboard and the Midwest with pieces including "The Position and Duties of European Refugees" and "The Ripening of Revolution in Ireland." ${ }^{14}$ Mitchel's mixture of antiimperialism and anti-industrialism was particularly attuned to the sensibility south of the Mason-Dixon Line. In I855 Mitchel moved to Tennessee and later to Virginia, before becoming notorious in the North for his defense of slavery and staunch support for the Confederacy.

Just as the 1848 rebellion in Ireland had been more symbolic than militarily significant, so the U.S. lecture tours of the exiles were exercises above all in the political theater of global republicanism. Their arrival had come at a fortuitous time for such ideas. In the early I850s, vocal interests in both North and South found common cause in venerating the heroes of recent European revolutions, either as part of the developing sectional dispute or through the internationalist solidarity, captured in Pierce's I 853 inaugural address, toward "the oppressed throughout the world ... [ [who] have turned their eyes hitherward."15 Crucially, Meagher and Mitchel also came hot on the heels of the visit of another hero of those European struggles. In I851, Lajos Kossuth, the leader of the short-lived Hungarian Revolution of I848-49, had arrived in the United States on a mission to raise funds for his nation's independence. The intense positive reception he received became a crystallizing event for the Young America movement and had a wider role in promoting fascination with European radicals. ${ }^{16}$ It also suggested a route for the rebels of Ireland's own I848 uprising. From jail in Bermuda, Mitchel had written of reading, "with a sense of returning life, the glorious Governor's impassioned harangues" as "the world once more hung enraptured on the firetipped tongue of a true orator." 17 Those seeking Irish independence could do worse than to emulate the illustrious Hungarian's exercises in mythmaking through oratory and public display. Lecturing offered not only an effective fund-raising exercise for the cause and for their own personal support but also a propaganda tool by which to cultivate an Irish American counterpublic and a broader network of liberal republican sympathy.

When their own turn came, this "theater" was stage-managed for maximum impact. Crowds camped out to await the arrival of Meagher's and Mitchel's ships; the men were paraded around Manhattan and Brooklyn at functions, receptions, and civic galas, and during I852 the "T. F. Meagher 
Polka" was performed nightly at Niblo's Theater. ${ }^{18}$ From the outset, Meagher and Mitchel made speeches that were widely transcribed in the press, and although some took place at dinners and other events, their public lectures were to prove the most lasting. When they lectured, they brought a sense of spectacle with them. Their stages were shared with noted veterans of previous Irish uprisings: "nearly three thousand" cheered Meagher on stage in Philadelphia alongside "John Binns, one of the patriots of I798," providing what one reporter called "a singular link" between the generations. In New York a band played Irish airs mingled with "Yankee Doodle." ${ }^{19}$ When Mitchel spoke at the Broadway Tabernacle, "behind the platform was suspended the flag of the Irish Republic," and a feverish ovation heralded his arrival. ${ }^{20}$ Lecturing in Brooklyn in I853, Meagher was presented with "a magnificent sword," and his speech was followed by numerous celebratory tributes. ${ }^{21}$ The previous year, the Convention of Civic Societies agreed to place Meagher at the head of a parade, with a stagecoach "handsomely decorated, to be drawn by six grey horses, banners, mottoes, \&c."22 The two men sometimes shared the stage as twin exiles, doubling the frenzied atmosphere.

Reports and accounts reveal Mitchel as the superior writer but Meagher as the more powerful orator. Some sources describe both in conventional fashion as "fiery" and "manly." 23 Their fervor and "frantic enthusiasm" were valued and read as moral authenticity: watching Meagher speak made a New York Tribune reporter's "breast swell with patriotism ... he appeared to feel all that he said, and his audience felt with him." ${ }^{24}$ Such histrionics were almost demanded by audiences, as when the press in St. Louis anticipated Mitchel's I856 appearance by hoping that it would be "in the style of the pike and vitriol school of popular insurrectionists." ${ }^{25}$ However, other observers appeared appalled by the overblown artifice of Meagher's style in particular. The New York correspondent for Frederick Douglass' Paper offered a skeptical account of seeing Meagher, describing him as "a man of some brains and more pretensions, [who] possesses all the wildness and ferocity of his class, tempered only by education and refinement." ${ }^{26}$ This writer also captured something of the mobile nature of the Irishman's platform style:

Irish hatred is now to be called up. Watch him. Observe every lineament of his face, every gesture, every expression. Now, he is the sly, cunning cat, sitting at the mouse hole, now-now to pounce upon his tiny victim ... now he is the savage butcher, with sleeves tucked up, ready to strike his victim, the big, burly, English bull. ... So wrapt [the onlookers'] feelings, so complete his acting, so perfect and intense his 
performance. A low, savage growl, and then a wild shout, and a fearful rush, and then the cry is "the English, the English, the hated English; up-up boys, and at 'em!"27

Yet curiously, others found Meagher and Mitchel not the firebrands they expected and instead described a controlled mode of public delivery. One reporter reviewing Meagher's performance in Philadelphia thought that he had "less fire and energy than we supposed; more brilliancy and more grace ... seldom does he leave the calm and regular strain of speech and rise with kindling warmth. But when he does so, all the orator shines in him." ${ }^{28}$

Mitchel was explicit about his intended audience, claiming that it was his aim to "address the Irish-born citizens of America upon the one great topic of this age." ${ }^{29}$ At times, when speaking before Hibernian Societies or other exclusively Irish organizations, this was certainly the case. We have little sense of the social makeup of such groupings, but the account of Meagher's lecture in Frederick Douglass' Paper demeaned one crowd as a Celtic rabble, frothing and animalistic:

Were you ever in a menagerie? . . . Passing Broadway, when just opposite the Tabernacle, the name Meagher caught my eye. After a moment's hesitation, I entered. What a sight! Here were thousands of wild Irish vociferating and gesticulating with a fury; the wildest imagination could not portray, and I shall not attempt a description. With their long scraggly hair over low brows, and narrow faces, with huge projecting teeth and dull sluggish eyes, they presented to the beholder a collection, overmatching in apparent ferocity, any wild animals hitherto gathered in this country, or I venture to believe, in the combined Zoological gardens of Europe. ${ }^{30}$

Such descriptions seemed to owe more to the racialized anti-Irish nativism of Know Nothing bombast than to the emancipatory ideals of one of the nation's premier reformist papers. Yet they remind us of the wedge that Irish newcomers drove between reform movements, from abolitionists to Whig educationalists. To some observers such lectures provided simply "a fair exhibit of the wild Irish in America." 31 For most of Meagher's and Mitchel's public lectures, accounts confirm that there was often a majority Irish base of support-and not just in the Eastern cities. In Cincinnati, for instance, a June I860 lecture by Mitchel was described as filled "mostly by countrymen of the lecturer." 32 Yet in other locations the audience seems to 
have been more mixed. Meagher's first biographer, for example, recalled the "fervid enthusiasm" of an Albany lecture that crossed "distinction of race, creed or class ... equal portions of native and naturalized citizens." ${ }^{33}$ As one might expect, Meagher's and Mitchel's lectures and movements were heavily debated and covered in the Irish American press, including the Nation in New York and the Pilot in Boston. Later both men established their own publications to help sustain and energize the nationalist community. Further, as the lecturers knew, transcripts of their words were also presented in the most prominent newspapers in each city as mainstream cultural events with mass appeal to readers beyond an ethnic audience. For instance, Mitchel's appearances in Boston were described in the first column of the New York Herald in 1853 , and the New York Times carried full transcriptions of Meagher's lectures. ${ }^{34}$

In this way, their performances had a dual rhetorical thrust. On one level, they functioned to shore up Irish diasporic identity, continuing the transatlantic political discourse prevalent since Daniel O'Connell's ascendancy a generation earlier. As Kerby Miller has argued, the East Coast Irish diaspora was "particularly receptive to nationalist interpretations of their experiences," and the predicament of exile and emigration was fertile ground for Young Ireland mythmakers to exploit. ${ }^{35}$ But rather than just mobilizing the Irish population of the Eastern cities, these lecturers were simultaneously speaking to a wider constituency of American liberalism. Both used emotive accounts of Irish struggle and misery to elicit sympathy, with Mitchel sketching the Ireland he left as settled into "a deeper and darker pall than ever. . . . Her children lay dying by myriads round her coasts, mourned only by the hoarse Atlantic." ${ }^{36}$ Both also deliberately inhabited the language of the American Revolution, with Mitchel opening a talk in Boston by praising "that famous spot of ground which your fathers held so nobly against the beleaguered battalions of England." ${ }^{37}$ He customarily peppered his speech with denunciations of the "malefactors . . . who now govern Europe, and more especially the Queen of Great Britain and Ireland," sentiments that elicited "immense cheering." 38 Their lectures, however, appealed to subtly distinct kinds of understandings of what a diasporic community or identity might entail.

Meagher was particularly keen to make his audiences identify not only with what he called "the inalienable inheritance of my poor country" but also with a broader culture of republicanism. ${ }^{39}$ He offered the vision of a global liberal commons and invited audiences to place the American republic within it. "The example of America," he told crowd after crowd, had taught 
Ireland "lessons of citizenship . . . those lessons of national spirit, industry and ambition, of religious toleration. ${ }^{40}$ And such a global commons was not only transatlantic but also transpacific. "To you, the citizens of America," he told audiences with reference to the future status of the Australia in which he had been imprisoned, "it must be pleasing indeed to behold a new republic, rising up to share with you the labours and the glories of a future before which the conceits of the old world shall be humbled." ${ }^{41}$ The energies that such a new republic might let loose, he maintained, would secure Irish freedom itself: "The seed will multiply, and borne back to the ancient land, will make the wilderness rejoice." ${ }^{42}$ He asked American audiences to place their nation within a revised teleology of global freedom, by doing so himself.

Similarly, Mitchel's lectures aimed to construct a new language of nationalism and a commons based on sensibility and shared opposition to monarchical oppression. He particularly appealed to "those whose taste or whose destiny had led them to interest themselves in the great public transactions of mankind. . . . Men might pretend to look on this old world drama with indifference," he conceded, "they might say the Eastern world was in its dotage, but in vain could they shut their ears to the echoes of the mighty revolution there going on." ${ }^{43}$ Having conscripted audiences into this global humanitarian consciousness through images of shared connection, he offered an opposite image to caution listeners of Britain's attempts to make the United States a pariah: "Think of it, to be shut off-God help us-from the diplomatic circle-to be held for Arabs and Gypsies-drawn off from civilized society, with whom it is impossible to be classified-to be stigmatized as a people bound by no compacts, respecting no law, dreaming of no justice, by whom? .. . It seems America is out of the pale of society according to the [London] Times." ${ }^{44}$ In his own person on the platform, Mitchel offered a living rebuke to such attempts at untying. "Though not long present in the body," Mitchel claimed on more than one occasion, "I have been many a year an American in spirit." ${ }^{45}$

The lectures of Meagher and Mitchel were therefore performances that resonated on multiple levels. First and most obvious was the outlet they provided for patriotic celebration from the Irish community. Also present was an element of cross-cultural curiosity on the part of a wider American public for such sentiments. A similar desire was well captured in a Dublin reporter's response to witnessing Kossuth lecture in England: "It is a grand thing to look upon such a very wonderful and admirable man-the man whom a noble and gallant people regard with intense and passionate veneration, as their leader, and humanly speaking, the star of their hope. ${ }^{\text {46 }}$ In the United 
States, fascination with the broader history of I 848 was in evidence throughout I850s culture, including various lectures on "The French Exiles." ${ }^{47}$ But what could be a more enticing prospect than the sight of an actual worldhistorical fugitive? Third, the speeches were appealing directly to the antimonarchical, Anglophobic spirit of the age; as one New York Herald report confirms, Mitchel consistently "wound up amid frantic enthusiasm with a stirring appeal to the hereditary hatred of England." 48 This was a sentiment, of course, that cut across the sectional divide. Meagher's and Mitchel's performances were rare examples of "acts" whose appeal genuinely straddled South and North, and they spoke widely in both. Finally, as famous escapees and exiles, both Meagher and Mitchel used the lecture hall as an extrajudicial extension of their trials, appealing to an imagined court of global public opinion and carrying over an earlier sense of testimony and defense. Yet as their tours continued, some of this initial import seemed to drain from the events: although Meagher was promoted on the East Coast in terms of the "fame of the orator and the cause," by the time he arrived in California his lectures were advertised simply as "an intellectual luxury."

The tours of Meagher and Mitchel were in fact far from uncontroversial or universally celebrated. Ralph Waldo Emerson was among many who saw their reception as simple celebrity worship: "Some foreign celebrity passes by ... Kossuth, or Dickens, Lord Morpeth or Meagher . . . the shout of welcome is echoed and caught from city to city . . . an oriental superlative of adulation." ${ }^{50}$ The Catholic press, partly incensed by Meagher's praise for anticlericals like Kossuth and the Italian revolutionary Giuseppe Mazzini, held a similar view. The Boston Pilot complained that "we cannot but smile at the adulation which a certain clique in that paradise of cliques, New York, continually throw at his face. . . . These insufferable toadies, who live on some passing excitement, continually assure him that he is the leader of our race in America." ${ }^{51}$ A glimpse from Meagher's New York lecture on Australia testifies to the controversies between the church and the nationalists: he railed against how "the Roman Catholic clergymen . . . did dishearten and restrain them. [Cheers and hisses. A voice- 'They will never do so again.' Loud cheers.] Ah! in that voice, continued Mr. Meagher, do I recognise the future freedom of down-trodden Ireland. [Vehement cheering.]"52 Others simply bridled at Meagher's and Mitchel's overly shrill Anglophobia, with audiences and booking committees in New Orleans and in Sacramento, California, taking offense at Meagher's "direct insult to the British nation."53 Moreover, their theatricality was not to everyone's taste. The New York Herald thought that their speeches were merely rhetorical display: "Amid the 
flowers of language that fell in great profusion from the speaker's lips, a single principle of practical application or immediate usefulness will be sought in vain." ${ }^{54}$

\section{Celts, Refugees, and Racial Theory}

While crowds were being roused into republican fervor by these exiles, the fate of Irish identity was being discussed in a quite different register elsewhere. The second way that speakers from Ireland thought together about the meanings of the diaspora was by posing as educators of their mixed audiences on questions of identity and culture. During the I850s, a range of performers spoke on such themes and articulated versions of Irishness more nuanced than the shrill identity politics that surrounded Meagher's appearances. In the hands of some lecturers, this took the form of the simple celebration of culture. One illustrative example was the Wexford-born dissenting Unitarian minister Henry Giles, who became a successful speaker during the I840s, championing Celtic culture with lectures on such topics as "The Spirit of Irish History" and "Irish Character, Mental and Moral." 55 He later informed his audiences that he had been "heard with generous interest ... in city halls and in village lyceums" since the early I840s, but by the end of that decade and the deepening of the famine and emigration crises, the story of Ireland had become "no longer novel. It is now not a story, but a drama; a black and fearful drama." ${ }^{56}$ Confronted with the mass immigration resulting from that "drama" and the demonization of the new Irish population, Giles aimed to forge common ground with non-Irish Americans through shared affection. ${ }^{57}$ At least one New York reviewer found the attempt convincing, arguing that "the pathos of his presentations of the sorrows of his favorite, Ireland, never fails to touch effectively all who listen to his story." 58 Giles's project was shared by other performers such as William E. Robinson, whose I852 talk "The Celtic and Anglo-Saxon Races" offered to redress "the American ignorance of Ireland," arguing that "in every department of art, literature, and science, the Celtic genius commands the world, and I must be pardoned if I decline to join in the general depreciation of this great race." ${ }^{\text {99 }}$

As the title of Robinson's lecture reveals, such themes were often expressed using the problematic language of popular racial theory. The I850s was a high point for pseudo-ethnographic typologies, thanks in part to the work of Scottish anatomist and popular lecturer Robert Knox. ${ }^{60}$ Ideas of AngloSaxon racial distinction and supremacy were common currency in high and 
low culture of the period. Traces stretch from the pages of the penny press to those of the London Times or New York's Christian Intelligencer, and from the incendiary speeches of urban controversialists such as Ned Buntline and anti-Catholic firebrands such as Charles Levin to the supposedly more rarefied addresses of Transcendentalists such as Theodore Parker and Ralph Waldo Emerson, both of whom devoted lectures to the topic during the early I850s. ${ }^{61}$

However, whereas Knox had argued for the superiority of the Anglo-Saxon, key Irish American cultural figures transformed his polygenist theories into an opportunity to counter negative stereotypes of savagery and superstition by celebrating the achievements and qualities of an imagined Celt. One of the most influential was Thomas D’Arcy McGee, another Young Ireland émigré and editor of Dublin's key nationalist journal, the Nation. In I848, sought by British authorities for attempting to incite rebellion, McGee escaped for the United States, where he became a leading ethnic spokesman. ${ }^{62}$ In the years before his emigration he had promoted a messianic theory of Celtic destiny, claiming that "Irish Catholic Celts were on a providential mission to transmit the One True Faith to the New World." ${ }^{\text {"3 }}$ In the pages of his journal the American Celt, he encouraged Irish Catholics to respond to nativist hostility with a politicized ethnic pride, promoting a magnificent Celtic past and the promise of patriotic Irish Americans as guarantors of democracy. When he took these ideas to the lecture platform in the mid-I850s, he was one of a number of speakers making a similar case. As lecturer Peter McLaughlin argued in his talk "Characteristics of the Irish Celt: Moral, Social and Religious," delivered in Brooklyn in I854, the migrant crisis of the previous decade meant that his topic was not marginal to a broader American public but a fundamental "subject . . . that concerns us all."

The most intriguing lecturer on this subject was John McElheran, a Belfast surgeon whose subversive ethnological theories had already earned him notoriety on the other side of the Atlantic. He had come to prominence after attacking what he called "the Saxon lie" in a series of articles and public talks in Dublin during I850-51, turning Knox's hierarchy of Saxon and Celt on its head. When McElheran's ideas were denounced in the Times of London, he defended them forcefully in a much-reprinted letter. ${ }^{65}$ Politically he, too, had become involved not only with Young Ireland but also with the Celtic Union, labor rights, and the universal franchise, and he spoke at the prominent I854 "national banquet" in Dublin to celebrate the safe arrival of John Mitchel in New York. By the end of that year he had come to the United States and begun advertising himself as a "lecturer on the races of men" 
whose notoriety preceded him. ${ }^{66}$ To the Irish American press, McElheran's apparent triumph over the anti-Celtic antipathies of the London press had made him both a true patriot and a figure of curiosity to a wider audience interested in the controversies of pseudoscience. His I854 lecture at New York's Academy of Medicine, on the "comparative anatomy of the human cranium," was reprinted in the New York Journal of Medicine and the Boston Pilot. The piece aimed to provide a maverick physiognomic basis for the Pan-Celtic resistance to the American nativism of McGee and others. McElheran's point of departure was still that of correcting misleading views of British history: "I appeal to history, but more to existing facts," he told audiences, "against the theory that England is Anglo-Saxon." In the United States he fleshed out this theme considerably, claiming that Celts, not Saxons, were the universal proponents of civic republican ideals and, further, that Celts were bulwarks against the "Saxon" erosion of liberty in the republic. Moreover, he reassured his audiences that due to "superior religiosity . . . by the Celts alone would Christianity be perpetuated here, and if American civilization and progress were to partake of the Christian character, it would be controlled and directed by the Celtic element." 68

These lectures are also important because, rather than offering mere dry rehearsals of contemporary scientific arguments, McElheran played racial distinctions for laughs. Reports suggest that he was as much entertainer as professor, interspersing the science "with a variety of Irish jokes, original versifications and occasional flights of Irish oratory." ${ }^{\prime 99}$ The highlight of his performances was a sequence in which he used illustrations to compare the cranial shape of notable Celts with those of the U.S. Founding Fathers. A reporter for Meagher's Irish News captured the scene of an I856 lecture by McElheran at the Broadway Tabernacle:

Upwards of one hundred large cartoons of the human head and face were cleverly used ... in support of his position that the strongly marked Yankee physiognomy is absolutely and purely Celtic. Great interest and laughter was excited. A sketch of a Paddy with a short pipe and battered hat was unmistakable. The Doctor removed his pipe, clapped on him a goatee, and presto he was a Frenchman. Away with the beard and his military cap and there stood revealed the noble features and brow of Washington ... the lecture gave great satisfaction. ${ }^{70}$

This was popular science at its most accessible and deceptively frivolous. But its resonance was immense. By unveiling the portrait in this way, and 
revealing the presence of Transcendental Celt in unexpected places, McElheran not only made the Irish white, in Noel Ignatiev's phrase, but he transformed the very conception of the republic into a Celtic achievement. The stripping away of layers offered a fascinating lesson in civics and the ironies of hyphenated identity, allowing the immigrants among audiences a dramatic metaphor for their own routes to assimilation and acceptance. ${ }^{71}$

The quest to understand the possibilities of global Irishness also became the key theme of Mitchel's work as editor and lecturer in the early years of his American exile. Speaking under such probing titles as "The Duties of the Immigrant," he demonstrated a willingness to move beyond shaping the myth of ' 48 into promoting a nuanced identity politics. In Boston, a city beset with a major migrant crisis, he addressed local concerns in a dual way. In a December I853 speech at the city's Revere House, he addressed members of the Irish diaspora and asked that they remember the duties they owed to the American republic in return for its protection: "I cordially join you in your just and hearty appreciation of the broad-based freedom and the all embracing generosity of this great republic. Let us remember what we owe to America; and, by faithfully and loyally discharging the duties of citizenship, let us endeavor to show both our gratitude to her, and our fitness for Democratic freedom and powers." 72 For a broader audience at the Music Hall on the same day, he met head-on critiques of the foreign sympathies of his countrymen, arguing, according to one reporter, that "it would be simply treason toward the commonwealth if he should pay more regard to the national claims or necessities ... than to those of the new country whose nationality he has voluntarily chosen to take upon him [immense applause]."73 To nativeborn Bostonians he underlined the point that all Americans were seeking asylum of some kind: "We are all equally Refugees; to us all alike the great free Republic of America opens her hospitable door and offers the sanctuary of an inviolable home." And he predicted that the republic might well find Irishmen the most eager and useful of recent immigrants at a future time of military strife: "War may come, and if it do, I know the land will have no more devoted defenders than her Irish citizens [tremendous applause]." ${ }^{74}$

Yet when that conflict came, the most prominent Irish Americans studied in this chapter found themselves on opposing sides of the Civil War: Meagher for the Union, Mitchel and McElheran for the Confederacy. This fact is unsurprising given that the issue of slavery served as a problematic absence in much of the lecture hall commentary I have discussed. The causes of Irish nationalism and abolition had long been in conflict-a result, in part, of the widespread fear among Irish nationalists that the antislavery movement 
would undermine American support for Irish political independence. The reframing of republicanism in Meagher's lectures had proved popular in the South, where many sympathized with his characterization of himself as trapped in a "fatal quarrel with a formidable government." 75 But other speakers discussed above went further. McElheran was not alone in insinuating in his lectures that abolition was a Saxon plan with London interests behind it. Mitchel also offered his audiences a skeptical view of the ineffective "transatlantic philanthropy" of Daniel O'Connell's abolition, and he began to argue for the expansion of slavery, offering a vision of an Irish American commons based on racial subordination. ${ }^{76}$

Mitchel's support for slavery was a rejection of one strand of AngloAmerican commonality. "The Irish appear to think no other people on earth deserving sympathy or liberty but themselves," wrote one observer. ${ }^{77}$ As a reporter from the National Anti-Slavery Standard put it, "It is plain from the opinion now expressed by Mr. Mitchel that he wages his warfare with England without any real principle of liberty at the bottom."78 Despite the iconic role played by the Irish lecture tours of Olaudah Equiano in the I79os, Charles Remond in I84I, or Frederick Douglass in I845, the overlaps between the antebellum Green and Black Atlantics were deeply fraught, at least in the lecture hall. ${ }^{79}$ Thinking together about the differences between Celt and Saxon often happened at the expense of African American sympathy.

\section{Conclusion}

Irish themes and speakers maintained their presence on the lecture stage into the postbellum period, and within the first fifty years after the Civil War the circuit would play host not only to nationalists such as Charles Parnell and Michael Davitt but also to those embodying Irish culture such as Oscar Wilde and W. B. Yeats. It was in the antebellum years, however, amid the turmoil of the Irish immigrant crisis, the low ebb for political opposition to British rule, and the divided loyalties of émigrés caught between North and South, that lecturing played its most important role in reimagining Irish America. As more is discovered by ongoing research, particularly into the social makeup and development of independent Irish lecture societies, this germinal moment will be fleshed out in far fuller fashion. Yet even in skeletal form, the Irish case study suggests a number of key truths about the nineteenth-century platform. 
The examples discussed here demonstrate that the lecture hall was not simply a place for the flattening out of social identities or conformity, but for the expression of complex ethnic affiliations. For many, lyceum attendance was intrinsic not just to the formation of bourgeois class identity but also, at a moment when ethnic hierarchies were coming into being, to the creation of a distinctively "white" public. Engagement with institutions perceived as civic, such as the lecture, was a marker on the road to social respectability, legitimacy, and prestige. The Irish case reminds us that we need to see the lecture as part of a continuum with other, more flamboyant, carnivalesque forms of nationalist expression, such as parades. Lecturing might have been a subtler, more muted space where nationalism overlapped with education and performance, but it was by no means separate from the larger animating forces it both reflected and helped to direct.

Equally, this chapter underlines the extent to which, for some groups, particularly marginalized or contentious subcultures, the lecture hall has been, above all, a space of politics. For Irish American performers and audiences, with particular conceptions of an oratory of resistance, the idea of the lecture was interchangeable with that of political agitation. Their history brings the role of lecturing as secular preaching into relief. The nationalism present on the podium and the Catholicism of the pulpit were engaged in a bitter struggle for the soul of Irish America, and both were frequently at odds with the ideology of individualism that lecture culture more broadly sought to promote.

During this crucial antebellum period, in which the East Coast, urban political class was struggling to know what to do with the energies of Irish nationalism, the lecture hall played a vital role in constructing new global Celtic identities. For Meagher and Mitchel, and for those sympathetic to their cause, the lecture hall became a voice of the exile community. It provided the perfect platform from which to cement the myth of ' 48 and to catalyze the next generation of Irish activists and thinkers, at home or throughout the diaspora, through the constant flow of newsprint coverage of their words at American lecterns. At the same time, the platform also became as powerful a medium as any other for those trying to define, challenge, or forge anew public understandings of Irish American identity. Multiple commentators responded to the supranational threat of Anglo-Saxonist ideology with a supranational response, constructing a Celtic international community joined by blood, customs, and history. 